\title{
Researcher-participant positioning and the discursive work of categories: Experiences from fieldwork in the mental health services
}

Agnes Ringer

\begin{abstract}
This paper reports on methodological experiences from an ethnographic study in psychiatric institutions in Denmark. Drawing on a poststructural framework and newer discussions within qualitative research that view methodological problems as sources of data, the paper analyzes how the challenges encountered in the fieldwork were indicative of discursive norms within the mental health services. It is argued that the multiple ways the researcher was positioned by participants revealed that the categories "patient" and "staff" were produced as polarized binaries with little leverage for negotiating positions in between. At the same time, it is shown that the patients find ways to resist the objectifying practices of the researcher as well as of the mental health services. The conclusions are discussed against recent attempts within the mental health services to promote a more patient-centered approach and involve patients in the treatment.
\end{abstract}

Keywords: qualitative methods, researcher positioning, field relations, ethnography, mental health

Please cite this article as:

Ringer, A. (2013). Researcher-participant positioning and the discursive work of categories: Experiences from fieldwork in the mental health services. Qualitative Studies, 4(1): 1-20

\section{Introduction}

In this paper I analyze methodological experiences from an ethnographic study on mental health institutions. The study focused on language within the mental health services - on how patients are talked to, with and about in psychiatric treatment. The mental health services of the Danish Region Zealand had initiated the study, based on a wish to promote a patient-centered approach and service user involvement. They were interested in the ability of the language used in communication with patients to either restrict or promote involving patients in the treatment. I was thus present at two psychiatric institutions with the purpose of producing data on language and service user involvement within mental health care.

The first institution in which the fieldwork took place was an outpatient clinic where patients lived at home and had regular or sporadic contact to the professionals. The second was a secured inpatient ward, where patients stayed for shorter or longer periods of time behind locked doors - but, by proving that they were well enough, could leave the grounds of the ward unsupervised. These two sites were chosen as they represent very different modes of organization within psychiatry. The first is for patients who are considered well enough to live at home, typically with voluntary contact to the mental health services. The other is for patients who are often considered too ill to even go for a walk alone - and are frequently sectioned or admitted on an involuntary basis. Three months were spent on participant observations of the everyday practices within the institutions - such as patient-professional meetings, therapeutic sessions, staff meetings, and treatment conferences. I also interviewed 13 patients and 11 members of staff. 
As the study progressed, it increasingly came to focus on language, not just as immediate communication between patients and professionals, but as naturalized forms of wider discourses that restrict and open up possibilities for how it was possible to define and think about patients in the mental health services (Foucault, 2005; 1991a; Holen, 2011; Speed, 2011). Thus, a poststructural framework became the framework for analysis. Such a framework attempts to look beyond the participants' immediate understandings of themselves and the world to analyze the discursive norms and repertoires that participants draw on when they talk. What is said in a meeting between a nurse and a patient, for instance, is regarded as a system of representations that reflects wider systems of meaning within the institution of psychiatry and within society (Speed, 2011). The language used may thus be said to draw on and construct discursive norms that create and restrict possibilities of defining who patients and professionals are. From this perspective, the discourses and norms available also set conditions that define who the researcher can be, since the researcher temporarily inhabits a part of the social worlds of the participants.

The paper focuses on the methodological challenges that I encountered during the fieldwork, particularly related to how the research participants reacted to and positioned the researcher. Drawing on newer debates that view methodological problems as sources of data, (e.g. Angrosino \& Mays de Pérez, 2000; Hastrup, 2010; Jensen, 2009; Järvinen \& Mik-Meyer, 2005; Savvakis \& Tzanakis, 2004), the paper proposes that by analyzing the positions that become available for the researcher in interactions with participants, it is possible to gain important insights on the features of the field under study. This type of understanding transcends the traditional division between methods and research outcomes in that it does not regard interactions with participants and methodological dilemmas solely as issues of method, but sees them as a point of departure for analysis. The paper specifically analyzes what the mutual processes of researcher positioning indicated in terms of the discursive norms of the institution of psychiatry. The cases used in the paper have all been selected as they are indicative of many dilemmatic situations in which the researcher's position became entangled in the web of the discourses of the institution.

\section{Researcher positioning as a starting point for analysis}

It is often stated as a goal that the ethnographic researcher finds a credible place for herself within the structures of the field she is entering; a position that provides opportunities for building trust and rapport so that she may be invited into different activities. Traditional discussions have been concerned with how the researcher may establish the best "role" in the field (e.g. Snow et al., 1986; see also Harrington, 2003 for an overview). The researcher is often thought to be able to take on roles initially when engaging with participants and stick to them throughout the research process. Problems with establishing a role, or with confusing roles, may be construed as problems of the individual researcher's method. However, newer debates within qualitative research argue that ethnographic researchers cannot unilaterally choose or control roles and options during fieldwork, no matter how carefully they have planned their studies (Harrington, 2003; Preissle \& Grant, 2004). Research participants are active in accepting, refusing or renegotiating a researcher's identity claims. Furthermore, participants rarely perceive the researcher as a unique and decontextualized individual, but define the researcher in terms of categories and norms that preexist in the field (Angrosino \& Mays de Pérez, 2000; Harrington, 2003). This is why the ways the researcher is understood by participants and the negotiations of access that the researcher encounters in the course of fieldwork may constitute an index to qualities, norms and structures in the social world of participants (Savvakis \& Tzanakis, 2004). 
The question of the position of the researcher seems to pose a particular problem in qualitative research within health institutions. Van der Geest \& Sarkodie (1998, p. 1375) note: "[qualitative researchers] in a hospital or clinic find themselves out of place. Not being a doctor, nurse or other type of health worker and not being a patient either makes their position somewhat awkward". Perhaps due to this reason, ethnographic research in mental health institutions in the past has sometimes been conducted covertly, with the researcher masquerading as a patient (e.g. Caudill, 1958; Rosenhan, 1973). Nowadays it is more common for researchers in health institutions to engage in overt research, dressing like, and following professionals (e.g. Barrett, 1996; Buus, 2005; Grigg et al, 2004; Holen, 2011; Johansen, 2006; Lester, 2009; Søndergaard, 2009; Warren, 1983; Weiss, 1993) - and thereby not infrequently be positioned as a member of staff by both professionals and patients. Many qualitative researchers in health institutions report on dilemmas associated with researcher positioning; however, the analytical implications of either being positioned as a patient or as a professional by the participants in the field are rarely discussed (van der Geest \& Finkler, 2004; Wind, 2009). At the same time, when different researchers in diverse times and settings have encountered similar challenges, it is unlikely that the dilemmas can solely be attributed to questions of methods or individual characteristics among the researchers (Jensen, 2009). Rather, they may be considered a starting point for understanding some structural qualities of the research field.

Taking these debates as points of departure, the paper applies the concept "positioning", derived from Bronwyn Davies and Rom Harré (1990) and Harré \& van Langenhove (1999), to analyze the researcher-participant relationship as a meeting between positions. Positioning may be understood as mutual negotiations of social positions that occur when people engage in conversation. When people position each other, they are assigning rights and duties of speaking and acting, based on pre-existing categories, metaphors and discourses (Harré \& van Langenhove, 1999). Positioning, therefore, always draws on wider discourses and norms, which are inseparable from the context of the interaction. At the same time, people can exercise notional choice; they can draw on a repertoire of multiple and even contradictory discourses in their self-and-other positioning. People are therefore active when they position themselves and others, but at the same time the amount of available discourses set the parameters of possible positions. Analyzing the processes of positioning that take place between researcher and participants may thus open up an understanding of the categories and discursive norms that are prevalent in the field and how they operate. In this way, a poststructural approach to the field relationship can be helpful in unpacking aspects of the field.

I will now turn to look at the positioning processes I became a part of during the fieldwork in the psychiatric institutions and how these can be understood as indicative of the discursive norms that operate in the mental health services. I begin by looking at the outpatient clinic. Because I was introduced to the clinic by the professionals and followed them to meetings with patients, I firstly discuss the positioning process I entered into with the professionals. I then move on to discuss how the frequent interaction with the professionals contributed to positioning me as a member of staff in the eyes of some patients. I look closely at an interview with a patient at the clinic and analyze how the ways I was positioned in the interview provided clues on the discursive norms that operate for patients. Subsequently I turn to look at the positioning processes I became a part of in the other setting of the fieldwork, the inpatient ward. I discuss how I strived to distance myself from a position as part of staff and I analyze the positioning processes I entered with the patients at the ward. Finally, I look at how the professionals at the ward reacted to me and the position of "least staff" that I strived to reach. In 
the conclusion I relate the discursive norms that emerged in the researcher positioning processes to the question of involving patients and their perspective in mental health care.

\section{First field: Researcher positioning at an outpatient psychiatric clinic}

In preparation for the entry to the fieldwork in the first institution, the outpatient clinic, I emphasized my clinical background as a psychologist and the study's affiliation with the mental health services in meetings with the professionals. The intention was that this might facilitate access (Grigg et al., 2004) and minimize the potential threat that being a complete stranger to psychiatric work may pose (Savvakis \& Tzanakis, 2004). Ethnographic literature in general encourages researchers to make themselves seem familiar and to find common grounds with the participants in order to "fit in" (Borbasi, Jackson \& Wilkes, 2005; Glesne \& Peshkin, 1999; Hammersley \& Atkinson, 2007; Harrington, 2003; Jorgenson, 1989). I wore a name tag with the logo of the mental health service, like the professionals, but one stating that I was a PhD student. I also tried to resemble the staff in clothing. I usually wore a clean, simple blouse, dark jeans and a suit-jacket. I was presented to the clinic by the professionals and I was introduced to patients by them. Following the professionals and getting access to patients with their help was practical and what seemed feasible. In any fieldwork, material and physical features of the world, as well as social and cultural aspects allow, encourage or block specific possibilities (Hastrup, 2010; Preissle \& Grant, 2004). Because the institution was a clinic, the professionals were there constantly during working hours; however the patients came and went. If I were to follow someone then, it was necessarily the professionals. I will now look at how some of the professionals at the ward positioned me as a critical evaluator in a position of power above them. I suggest that this is indicative of a discursive norm among the professionals to be wary of criticism in the face of recent standardization processes.

\section{Standardization and the researcher as a representative of the system}

One of the professionals says "I have something for our group therapy, but I almost don't dare to ask with Agnes here. I have a test in English, the newest test that is not translated to Danish yet. Isn't it okay if I use the English one? Is that okay?" Everyone says that it is all right. She looks at me with an inquiring look and asks if I have any objections. I answer "No, not at all".

\section{Fieldnotes, outpatient clinic}

The fragment above is derived from the staff morning meeting during the first day of fieldwork at the clinic. The team member's statement positions the researcher as someone who has the right to veto a decision approved by the team - and therefore in a superior position to them. Although I had tried to position myself as a naïve student among the professionals and said that I was there to learn from them, there were numerous examples from my fieldnotes of the professionals reacting to my presence with self-consciousness and something akin to submissiveness. During the fieldwork I interpreted these reactions as methodological problems. Perhaps I had not explained the aim of the study well enough or I had chosen the wrong approach. However, as the number of similar instances grew, I began to understand the professionals' positioning of me as more than problems of access. The reactions of these team members seemed to extend the relationship to me as a person and indicated that many of the professionals generally expected to be surveyed and criticized by outsiders. The health services in Denmark have been subject to an increased level of standardization and neo-liberal governing reforms (Holen, 2011; Magnussen, Vrangbæk \& Saltman, 2009) - and the team was 
working hard on implementing these. Their progress was regularly surveyed, and praise or reprimands were given based on the team's efforts. Although some level of suspicion and wariness towards the ethnographic researcher is not uncommon in fieldwork in general (DeWalt \& DeWalt, 2003; Harrington, 2003), it appeared that the specific positioning of the researcher as powerful and critical was connected to a discursive climate induced by the neoliberal reforms. In the other setting of the fieldwork, the inpatient ward, a nurse even told me directly that some of her colleagues regarded me as a spy, and that in these times of standardization and quality development one can never be too sure. This indicates that the researcher positioning processes could be read as indicative of the discursive norms that operated in the context. The prevalence of neoliberal discourses in mental health care thus seemed to have affected how the professionals could position themselves towards me. It was important for them not to be perceived as unprofessional, incompetent or to "lose face". In such a context, following the correct standard procedure became an important frame of reference for professionalism. The guidelines and benchmarking, intended to provide a higher standard of care, in practice therefore seemed to undermine the autonomy of professionals and made them cautious of making independent decisions (Holen, 2011; Speed, 2011).

Following staff, my contact to the patients was mediated by the professionals and they influenced who, among the patients, I could interview and join in meetings. This provided few opportunities to negotiate or destabilize the position (Spanger, 2010). Although I emphasized confidentiality and my independence as a researcher, for some of the patients my position as researcher became blurred with the professionals. In the next section I look closely at the processes of researcher positioning during an interview with a patient, Frederik. The case is chosen as it is illustrative of the way many patients were inclined to position me as one of the professionals at the clinic. Furthermore, the case illustrates that a researcher position as "part of staff" sometimes had consequences for the way patients found it possible to interact with me. I argue that the seemingly methodological problems that arose during the interview were indicative of a norm of the primacy of biomedical discourses within psychiatric care, excluding and rendering problematic alternative understandings of distress. However, I also argue the norm of bio-medicine does not become entirely encompassing for how patients may define themselves in other contexts.

\section{Biomedical discourses and the researcher as a member of staff}

Frederik was a man in his twenties who had been sentenced to treatment and medication following a minor felony. His main psychiatric contact, the nurse Magda, told me that Frederik was a co-operative and low-maintenance patient with whom she had a good workingrelationship. He had agreed to have me observe his meeting with Magda, and later interview him. As many professionals, Magda introduced me as a psychologist working on a research project. During the meeting Magda and Frederik mainly talked about medication. Frederik had stopped taking his medication for a few days and said that not taking it had made him feel better. Magda said that it was dangerous for him to experiment with it and it would be better to make an appointment with the doctor to make adjustments. She also said that she was obliged to mention that due to his sentence, it was compulsory for Frederik to take medication, and not doing so could lead to involuntary hospitalization. Although this element of coercion was present, the meeting was kept in a friendly, understanding and familiar tone. During the meeting Magda made some further references to me and my status as a psychologist.

Later the same day I interviewed Frederik. Trying to avoid a position as part of staff from the beginning, I had brought fruit and chocolate with me to the interview. As with all interviews I 
conducted, I started by asking about his life before entering psychiatry. This choice was motivated by a wish to not focus immediately on mental health issues (Deroche \& Lahman, 2008) and to diverge as much as possible from a patient-professional meeting. However, Frederik answered that there was nothing "noteworthy" [bemærkelsesværdigt] about his life prior to hospitalization. Thereby he applied a criterion of topic-relevance from a biomedical discourse, which prioritizes issues directly related to illness and distress, while topics concerning other parts of life often are deemed less relevant (Boyle, 2011; Holen \& Ahrenkiel, 2011). Despite my attempts, this situated the interview within the discursive genre (Wetherell, 2010, p. 18) of a patient-professional meeting, with me positioned as the professional.

\begin{abstract}
Agnes: So what happened?
Frederik: Mm, But it was, that is (.) if you call it a psychosis or whatever you might call it, er, what happened anyway was, er, that my brain anyway played (.) a thought trick and my life, and made all sorts of things (.) yeah, it is also written in my file, er, what happened back then (.) er, I almost can't even explain it but, but I'm almost tired of talking about it.
\end{abstract}

\title{
Interview with Frederik
}

Within a bio-medical discourse mental distress and diagnoses are understood as underlying biological forces that act upon a person's personality and identity (Parker et al., 1995; Rapley, Moncrieff \& Dillon, 2011). By talking about the brain playing a trick, Frederik positions himself as a repository for cerebral forces and uses the psychiatric term "psychosis" to make sense of his experiences. He implies that his patient file may provide me with information, perhaps more factual and objective information than he could provide. I did look at medical records as part of the study and I had asked for his consent for getting access to the file. As I had explained, my interest in the file was to see how professionals wrote about patients, not to get information on medical conditions. However, Frederik positions me as a person interested in expert statements on his psychiatric history - and himself as someone not well suited to provide these, or less suited than a patient record written by professionals. The statement that he is tired of talking about it further indicates that he does not wish to elaborate. However, the fragment also seems to indicate the existence of other possible discourses, specifically in the statement "psychosis or whatever you call it", even though these do not become immediately available. Later in the interview he described his first hospitalization:

A: What did you think about it at the time [during the first hospitalization]?

F: At the time I thought it was a terrible thing [noget herrens noget], it was phew! You shouldn't be here, like, I don't think it's good [rise in tempo of speech] because I am not sick or I am not, there is nothing wrong with me or what can you say (A: $\mathrm{mm}$ ) So, so I fought like, a little against, like, that, the idea about it (A: $\mathrm{mm}$ ) erm (5 s.) Erm, and I don't know if I still do, like a little (A: $\mathrm{mm}$ ) but erm, I don't really know what I think about it (A: $\mathrm{mm}$ ) with regards to just that. I haven't thought that much about it, heh [laughs], it's just something that has helped me, just through a period of time.

A: What has helped you?

F: Psychiatry

A: $\mathrm{Mm}$

(11 s.)

Interview with Frederik 
Here, Frederik first talks about himself as someone who once did not think he belonged in a psychiatric ward - as someone who did not consider himself ill and was oppositional to the mental health services. Thereby he invokes potentially anti-psychiatric discourses (Speed, 2011). He also implies that this is a position he currently may identify with. Then he seems to wish to shake the position off by saying that he has not thought it well through. This may serve to make his previous account seem more throwaway (Wetherell, 2010), as if it was something he just thought of now. Jonathan Potter (1997) has coined the term stake inoculation for discursive strategies that people may use when they wish to say something potentially bold, but then do not wish to be perceived as having a stake or interest in a certain position. This may have the function of preventing the interlocutor from undermining their accounts. For Frederik, the "I don't know if I still do", "I really don't know what to think about it", "I haven't thought that much about it" and the subsequent laugh, may function as just that; as a shield against a possible criticism or judgment of him, thereby positioning me as a person who could potentially undermine him. In response to many other questions, Frederik answered in a similar evasive or truncated manner and I grew increasingly frustrated that the interview was not proceeding well.

Alternative discourses and reworking the position of staff

Halfway into the interview, Frederik and I took a coffee-break and I turned off the recorder. I felt it necessary to explicitly readdress the question of my position. I told Frederik that it was true that I had studied psychology, but I was not a mental health professional. I did not have specific preconceptions about who and what may be considered ill. I was a researcher interested in his experiences. When we resumed the interview, this seemed to have caused a shift in Frederik's way of addressing me and the stories he told. He asked if I was interested in hearing more about the voices he heard, despite previously stating that he was "almost tired of talking about it". He explained in details how he perceived the voices to be external to him, that they were of an abstract spiritual and sometimes positive nature, and not pathological. At the same time, he said he believed he could not share these thoughts with the mental health staff:

F: I just think that feeling comfortable and feeling, feeling comfortable with saying what you, kind of what your inner torments are and because erm, I feel like they [mental health professionals] understand it one way, or the way that is $\mathrm{u}-$, the prevailing understanding (A: $\mathrm{mm}$ ) and I understand it in a totally different way and I don't think I can explain myself out of it like that: "I see it this way instead". So, so I keep it to myself instead and I try to avoid talking to them about it (A: $\mathrm{mm}$ ) Yes, I have always seen it as something that just needs to be gotten over with.

Interview with Frederik

In this fragment towards the end of the interview, Frederik positions himself as someone who has learned to manage the contact with mental health professionals, specifically by avoiding disclosures of too much personal information. A similar dynamic appeared to have taken place between interviewer and interviewee throughout the first part of the interview, when he had positioned me as a mental health professional. Researchers have noted the resemblance between the qualitative research interview and clinical or psychotherapeutic encounters (Fog, 2004; Kvale \& Brinkmann, 2009). They note that there is a risk that the intimacy of an interview situation may cause participants to reveal personal information they will later regret. This is an important point that should always be taken into consideration when doing interview research, 
perhaps especially within clinical settings. For Frederik, however, the proximity of the research interview to a clinical session and the positioning of me as a mental health professional seemed to have had the opposite effect. Instead of excessively revealing personal information, he wished to reveal as little personal information as possible, when that information potentially diverged from a mainstream psychiatric discourse. It was only when the interviewer could be positioned outside of the category "mental health professional" that he could draw on alternative discourses than a dominant psychiatric one.

At first glance, Frederik's uneasiness and evasive answers in the first part of the interview might have been thought of as mere technical problems between the interviewer and the informant. However, a closer look suggests that the methodical problems become meaningful in the light of discursive norms and subject positions within the institution. Barrett (1996) and Parker et al. (1995) have noted that through repeated interactions with professionals, psychiatric patients learn to define their experiences in relation to professional categories and norms - and thus learn to become competent patients. On the other hand, patients risk rejection or being discredited if they position themselves within less established forms of knowledge (Parker et al., 1995). Throughout the fieldwork, I learned that there was a potential risk involved for patients who admitted to unconventional understandings of their distress. Patients who said they were not ill or whose explanations for their distress diverged a lot from psychiatric discourses were frequently labeled as "lacking in insight" into their illnesses (Dillon, 2011). Within the mental health services, patients who were thought of as "lacking in insight" were often considered uncooperative and very ill. Consequently, it was not an attractive position to be placed in. Seen in this light, Frederik's strategies for mitigating potentially problematic utterances in the interview can be seen as a way of shielding against being positioned as "lacking in insight" by the interviewer - whom he perceived to be part of the professional group. What I experienced during the interview as technical problems thus rather seemed to be an indication of norms and expectations regarding how patients could talk and position themselves within the mental health services in order to be perceived as easy to deal with and co-operative.

What the case of Frederik further illustrates is not that alternative discourses of distress become absent in a person's self-constructions when becoming a psychiatric patient, but rather that there can be difficulties and risks involved in expressing these in interactions with professionals. At the same time, the interview illustrates that there is a potential for resisting psychiatric discourses in accordance with the demands of the discursive context (Parker et al., 1995). As much as reductionist discourses of illness and disease may become the main frame of reference in meetings with professionals, they do not necessarily become generalized to how patients define and position themselves in other contexts. This showed me the importance of studying not only how patients are talked to and about in the mental health services, but also how they themselves talk about the mental health services - and the self-constructions that become available to them when doing so. I thus became aware of the importance of conducting interviews as part of the fieldwork. By basing most of the material on observations and by following professionals, I risked ignoring discourses that could sometimes not be expressed in patient-professional interactions.

\section{Second field: Negotiating "least staff" researcher positions at a secured psychiatric ward}

The interview with Frederik had made it clear that if I wished to gain access to discourses that were sometimes silenced in interactions with professionals, it was important that the patients did not position me as part of the professional group. In the second field, the secured inpatient 
ward, I therefore sought to negotiate an approach that would make it possible for me to be positioned as "least staff"1: to diverge from the staff category as much as possible and not be seen as affiliated with them. On the entrance meetings with the professionals of the ward during which I told them about the study, I therefore explained that I wished to get to know the patients first and spend time with them, as my research design made it important that the patients did not think of me as part of staff. As I also wished to produce data on how the professionals talked about the patients in their absence, I added that towards the end of the fieldwork I would like to deviate from this rule - and join the professionals on staff meetings and interview them.

In order to avoid being positioned as staff, when entering the ward I had to create a visible connection with the patients. Having made up my mind to position myself as recognizable to patients, I was aware to signal with my body signs (Søndergaard, 2006), clothes and body language, a stronger belonging to them than to the professionals (Estroff, 1982). I learned to wear worn jeans and loose t-shirts, no jewelry, and sport shoes, thereby resembling how some of the patients dressed. I refrained from wearing an identity tag or a security alarm like the staff. I avoided going near the staff room in the beginning of the field work. Only professionals were allowed into the staff room, and patients would knock on the door and stand outside while talking to a professional. I also joined the patients' activities rather than the professionals: used the patient lavatory, rather than the one reserved for staff, drank coffee when it was served to patients, and, lastly, went to the smoking room with the patients who smoked. Smoking turned out to be an important activity for many patients and some spent a great proportion of their time in the smoking room. The strategy opened a forum for just sitting with the smoking patients on the pretense that I "just needed a smoke". At other times I attempted to "just hang around", sitting relaxed and silent, folded up on the couch (Estroff, 1982) in the common room. However, for my identity claims as "least staff" to work, they had to be accepted by the research participants (Harrington, 2003). The next section looks at how the patients at the ward reacted to and positioned the researcher in light of my attempts to position myself as "least staff". I discuss that my attempted positioning as "least staff" triggered more implicit or explicit resistance from the patients than what I had experiences at the clinic. The resistance to me, I suggest, was associated with a resistance to objectification; a resistance that at the same time could be difficult for patients to express when interacting with professionals.

\section{Decoding the researcher's interests and resistance to objectification}

Unlike the patients at the clinic, with whom I mostly talked during formal interviews or observed during meetings with professionals; with my "least staff" identity-claim I was able to develop more informal and long-lasting relationships with many patients at the ward. However, just as with the interview with Frederik at the clinic, there was a tendency that some patients at the ward initially positioned me as interested in their "illness".

I am sitting with some of the female patients in the activity room. One of them has brought a kit for painting and decorating finger nails. They have asked if I want to join them and also have my nails painted and I have happily agreed. I bring some sweets that

\footnotetext{
${ }^{1}$ The term "least staff" is inspired by Nancy Mandell (1988), who, while doing research on children's social worlds in nurseries, developed an approach she calls the "least adult" role. Mandell's "least adult" role is practiced by her participating as one of the children and subordinating to the authority of the teachers, although with a constant awareness that she cannot actually become one of the children. More recently in a Danish context, Hanne Warming (2005) has redeveloped the concept within a poststructural framework.
} 
I have kept in my backpack and we share them while we are getting our nails painted by Julia, who has been a patient at the ward for some time. Julia says: "Ha, you're giving us sweets so that we will tell you about our mental problems". I answer that I'm actually more interested in how they experience the mental health services than in their problems, "but", I jokingly add, "it is correct that I am bribing you". We laugh.

Fieldnotes, inpatient ward

Julia's attempt to decode the researcher's aims and interests reveals something about what patients at a psychiatric ward might expect others to find interesting about them (Jensen, 2009). She is used to talking about her personal difficulties with professionals and knows that being a psychiatric patient, having "mental problems" and a psychiatric diagnosis, positions her as different from the norm; a norm of which the researcher in this case is a representative. At the same time she makes fun of the researcher's intentions and practices. The researcher is positioned as someone who wishes to objecitfy the patients by studying their "mental problems" - but at the same time doesn't have the authority of the professionals to do so - and thus is forced to bribe her way to gaining access. Julia's reaction and articulation of what she perecives to be the researcher's aims may be seen as a type of resistance against being objectified by the researcher's gaze (Foucault, 2003; Jensen, 2009). She practices resistance by the use of irony - and throughout the fieldwork there were numerous examples of her reacting to my presence this way. In the former setting, the outpatient clinic, I wrote fieldnotes during almost all my observations. The professionals had sometimes commented on this, but the patients never mentioned my writing practices. At the ward, however, the informality of my interactions with the patients often prevented me from taking notes (Emerson, Fretz \& Shaw, 1995). In the few situations in which I tried jotting some words down in the presence of Julia, she commented on it and mocked me: "Oh there the journalist appeared in her!" or "Are you getting anything to write about? You love this, don't you?". Her reactions may be read as confronting the researcher with the fact that the researcher, because of her academic position, has the possibility of producing authoritative accounts on the patients (Jensen, 2009). Thus, they are an ironic comment on the power that lies in the objectifying practices of the researcher - and at the same time an indication that she opposes to the objectification. Other patients sometimes showed resistance to the researcher's objectifying practices by avoiding talking about the things the researcher was interested in, or what they thought the researcher was interested in. In my fieldnotes I have written about another patient, Mark:

Mark walked by my side all day today and followed me around, but he did not want to talk about the mental health services when I asked about his experiences of them. Whenever I tried asking him he changed the subject and talked about different songs he had listened to, films he had seen and books that interested him. He asked me many questions about these and whether I had heard of them. I finally asked him directly if he would like to participate in an interview, but he said no. I asked him why and he said he doesn't like to blabber and go on and on. I asked what he meant and he said "well, about things like my illness and stuff". I said that I actually rather wanted to ask him about how he experiences the mental health services. He answered "it's personal".

Fieldnotes, inpatient ward

My questions about Mark's experiences of psychiatric care places him in the position of "psychiatric patient". Thereby I implicitly point out the differences between us, positioning 
myself as the norm and him as deviant from it. Mark's avoidance of my questions and resistance to participating in an interview can be read as him resisting precisely the categorization as "psychiatric patient". Like Julia he positions the researcher as primarily interested in a biomedical condition - "my illness" - and distances himself from that position. Experiencing or thinking that others may find you interesting only because of an illness that makes you deviant and perhaps inferior to the norm, calls for a rejection of that position. Mark's response is to disidentify (Jensen, 2009; Skeggs, 1997) from the position of "mentally ill" by rejecting any topics introduced by the researcher that hint at his status as psychiatric patient. Thereby he markedly distances himself from the position he perceives the researcher to place him in - and normalizes the situation by drawing on a repertoire of topics from everyday conversations: books, films and music.

Mark and Julia's mockery and resistance to me can be read as subtle antagonisms within the institution and in society moving into the researcher's relations with the participants. They both expected me to be interested primarily in their illness, but seemed to resist this classification of them. It is interesting that the patients in the former field, the outpatient clinic, had not in the same way reacted with irony or resistance when I was introduced to them by professionals. One interpretation of this could be that when the patients had me positioned as part of the professional group they expected me to objectify them and, as in the case of Frederik, objectified themselves to me - by constructing themselves as passive repositories of pathology (Speed, 2011). This can be tied to Foucauldian notions of how psychiatric patients learn to make themselves objects for biomedical interventions and in the light of these learn to reflect on themselves as objects (Foucault, 2003; 2005). Such a process of objectification may become invisible for patients, as it just becomes a naturalized form of interaction within the mental health services (Barrett, 1996). However, engaging with the researcher, who shifted positions between regular talk and objectifying note-taking, might have made the objectifying practices more visible. The patients' reactions to me can thus be read as an index to the varying and complex forms of resistance that become available to patients in different discursive contexts. In the next section, I will look closely at one specific context of my interactions with the patients, the smoking room. I argue that the patients' reactions to my presence there and the positioning of me as a "fellow smoker" point to the importance of physical space in creating pockets of resistance for the patients.

The symbolic meaning of the smoking room and the researcher as a fellow smoker

The patients Dina, Julia and Laura go out to smoke in the smoking room. I take out my own pack of cigarettes and go out with them. Dina makes a surprised, slightly disapproving face and asks: "What are you doing?!". Laura answers: "she wants to smoke". I ask if that is alright. Julia says "of course it is". "Oh", Dina says, "I thought you were from the staff, they're not allowed to smoke with us". I say no I'm not and I introduce myself. She answers: "Oh, so you're the one doing that study". I say yes. They keep talking. Dina turns to the group and says that she tried to burn her jeans yesterday. Then she describes a suicide attempt involving 300 painkillers. She explains that after she had swallowed them she called her boyfriend who had gotten her an ambulance. She says that she has done the same thing four times before.

Fieldnotes, inpatient ward 
Joining the patients in the designated smoking area - the smoking room - turned out to be the most important way for me to attempt being positioned as least staff. As I learned from Dina's reaction to my presence, smoking in the smoking room was an activity reserved for the patients alone; the professionals were not allowed to smoke with them. When the specific event above took place I had already joined Laura and Julia in the smoking room on numerous occasions. Dina had largely stayed in her own room and hence I had not had the chance to speak to her before. Dina's negative reactions to my presence when she thought I was part of staff, and her subsequent willingness to speak openly about her suicide attempt, when the others assured it was legitimate for me to be there, can be read as indicative of some of the norms and practices guarding the patients' everyday interactions at the ward. As the professionals were afraid that some patients would disclose personal information they may later regret, the ward had a rule that patients were not allowed to talk to each other about emotional distress. I observed a few times how the rule was implemented: if a patient attempted to share experiences of distress with other patients in front of professionals, that person was escorted away from the other patients and invited instead to have a talk with one of the professionals. Most patients thus learned to balance what they could say to each other in the ordinary spaces of the ward - and the topics discussed were typically on mundane, everyday themes. However, Dina's openness about her suicide attempt and positioning of me as a fellow smoker in the context of the smoking room indicates the "otherness" of this particular space. In it, as opposed to other contexts of the ward, the patients could talk freely about their distress and negotiate the topics of discussion among themselves.

Perhaps because of its status as a special or "other" place, the smoking room was subject to discussions and conflicts between professionals and patients. Explaining to me that they wished to reduce the time spent in the smoking room and prevent the formation of cliques, the professionals introduced a rule that smokers were not allowed to sit on the floor while smoking, but had to stand up. This rule was subject to discussions both within the patient group and during common meetings with professionals. Not all patients showed interest in the rule, but most smokers disagreed with it. The conflict led to tensions regarding me and who I would side with. As I also wished to be positioned as trustworthy by the professionals, I adhered to the ban on sitting down, but kept going to the smoking room with the smoking patients.

I go out to smoke with Hanna, David and Carl. The nurses Niklas and Ida are sitting in the common room just by the smoking room watching television. Hanna sits down by the wall in the smoking room, so the nurses can't see her. David, who is standing in front of the transparent glass door, visible to the professionals, starts to sit down too, but rises quickly again. We talk about Hanna's plans to move to a group home [..] Then Hanna turns to me and says jokingly: "You know that you are violating the rules. You are talking out here". I decide to go along, I cover my mouth and I say "sorry" with an ironic tone.

Fieldnotes, inpatient ward

Hanna introduces a discourse of resistance against the rules evoked by the professionals. She exaggerates the ban on sitting down and calls it a ban on talking, thereby positioning the professionals as unnecessarily authoritarian. At the same time, she positions me as someone who, like her, is violating the rules and is oppositional to them. Thereby she constructs sameness and commonality (Khawaja \& Mørck, 2008), implying that we have the same rules to adjust to - as we are engaging in the same activity. Although I had not earlier addressed the 
conflict, in an effort to position myself as trustworthy, I accepted the position, implicitly marking my sympathy to her viewpoints and distancing myself from the rules in a slightly mocking fashion. This action was a way of "doing trust" (Jefferson \& Huniche, 2009), creating a connection with Hanna by positioning myself off the staff category. I thus co-constructed the discourse of resistance towards the professionals' authority that Hanna initiated.

The positioning of me as a fellow smoker in the context of the smoking room, I suggest, points to the "otherness" of this specific place, in that it could provide a pocket of explicit resistance for the patients at the ward. At the ward, all other places were potentially places of "treatment" where the patients were "being treated" and the professionals were treating them (McGrath, 2012). Patients were openly subject to the psychiatric gaze - expressed in fine mechanism of surveillance and control (Foucault, 1991b; 2003). The interactions in the smoking room, however, provided occasions for other types of positioning than "patient being treated" and in it, the patients could negotiate topics of conversation without the influence of professionals. The smoking room was thus produced as a "private space" (McGrath, 2012) that could temporarily destabilize a patient position. Had I not been invited into a position as a fellow smoker, this function of the smoking room would have escaped my attention. The positioning of the researcher as a fellow smoker thus made visible the norms and practices of patients in the particular context of the smoking room. The "otherness" of the smoking room in term indicated some aspect of the discursive norms shaping how to be a patient in the other spaces at the ward; often involving negotiating a patient position in an institutionally sanctioned manner.

As much as some patients came to position me as a "fellow smoker" or outside of the staff category in many instances, the professionals of the ward appeared to position me as belonging to the category "most staff" or "least patient". The next section analyzes how some professionals at the ward expected me to participate with the rights and duties inherent in a staff position. I suggest that this is indicative of a discursive norm within the mental health services that is based on a polarized dichotomy of "normality" and "pathology".

\section{Discourses of pathology and normality - the researcher as "least patient"}

Because I wished to establish a "least staff" position at the ward, in the early days of fieldwork I had rare contact with most professionals. However a few professionals did approach me, mostly two nurses and a nursing student. At one point during the first weeks of the fieldwork, the nurse Andrea approached me when I was alone in the common room and addressed a problem they were experiencing. It was prohibited to have romantic relationships at the ward, but the patients Clara and Frank had formed a couple:

Andrea sighs and says that there is a bad atmosphere at the ward because they have a lot of personality disordered patients at the moment. She says that she has noticed that I walk around without a security alarm [...] She goes to the staff room and brings an alarm that she gives me. She says: "Hey by the way, if you see Clara and Frank kissing, you can correct them" I answer "ehhmmmm... I don't think I can". She says: "Then go get Stine [another nurse] to do it, she will be at work while I am away now, so she can correct them. They are not allowed to kiss; it creates an uneasy atmosphere among the other patients." She shows me how the alarm works and that she wears hers under her shirt. I go to the toilet and I try out different solutions to hide the alarm. I think about how wearing it really associates me with the staff.

Fieldnotes, inpatient ward 
Here, despite the explicit efforts I had made to distance myself from the category "staff", Andrea expects me to participate with the same rights and duties as the professionals. She constructs the patients as easy to distress and positions me and herself outside the category patient. As I also wished to be positioned as trustworthy by her and the other professionals, I accepted the alarm and I did not openly oppose the idea of fetching a nurse if I saw the patients kiss, although I did not make use of it later on, as it would have compromised a position as trustworthy among patients. The position that I was invited into and my response to it were further made more complex by some incidents that had occurred recently: one patient had acted threateningly towards me, which had made me more willing to accept the alarm. This shows that Andrea's concern and wish to protect me, although she probably was unaware of the incidents, was not meaningless or uncalled for. In the light of this, I also began to experience some patients as unpredictable an easy to distress, which at times complicated my position and relationship to them. This indicates how the positions of researcher, professional, and patient intersected and produced relationships that could not be controlled or predicted prior to the fieldwork. The researcher-participant positioning had to be constantly negotiated and renegotiated, if I wished to be positioned as trustworthy by all participants.

The position that the professionals invited me into was a dilemmatic one. While an increasing amount of patients came to position me frequently as "least staff", the professionals usually seemed to position me as "least patient" when I interacted with them. The issues of belonging to one group or the other became increasingly challenging when I started having more regular contact with the professionals. I felt as if I was being disloyal to one of the groups when I was with the other. The challenges were amplified when I was with both professionals and patients in the same room:

I'm sitting in the common room with Julia and with the nursing intern Jasmin. The patient Emma comes in and sits down next to me. Frank comes in and sits down too. Emma asks Frank: "What actually happened between you and Clara, are you a couple now, or what?" Frank says that they are, that he only wants Clara and that's the way it is. Emma asks if he is in love with her. Frank says that he is very much in love, and then he leaves. The nursing intern Jasmin looks at me and says "we really have to report this to the other staff". I mumble indistinctly that I won't. The others go out to smoke. I ask Jasmin if she thinks it's okay if I join them. She says she thinks it's alright. According to house rules, she says, one is not allowed to join the patients, but maybe that has nothing to do with me. I go to the smoking room. The patients in there are talking about Frank and Clara. They say they think it's disgusting. Julia says that they're not allowed to kiss according to house rules. She looks at me and says: "yeah, Jasmin said that she would tell the staff". I say "I won't tell, it's important that you know that I won't tell the things you say to me".

\section{Fieldnotes, inpatient ward}

Here, the nursing student Jasmin, like Andrea, assigns to me the same duties as the professionals: reporting a violation of house rules. And just as with Andrea, I found it difficult to respond properly. Not opposing Jasmin's suggestion that we should report the violation to the other members of staff would have positioned me as untrustworthy in the eyes of the witnessing patients. However opposing Jasmin's suggestion may have positioned me as 
disloyal from her perspective. My response was to very hesitantly disagree with Jasmin at first and later to attempt to disidentify from the staff category explicitly among the patients.

Again, here I suggest that the dilemmas encountered with Jasmin and Andrea can be read as indicative of norms in the mental health services. The often mutually exclusive expectations about who I was and what my duties were indicate that the staff and patient categories were produced as polarized binary pairs. The "we" that the members of staff constructed with the researcher was not based on a commonality of people participating in similar activities or presenting similar body signs, as I had strived to act like and to look different from the professionals. The common link between us seemed to be based on something else; a discourse of pathology and normality, offering the category "mentally sane" as a decisive marker of commonality between the researcher and the nurses. According to the discourse, since the researcher is not a psychiatric patient, and therefore in the "normality" end of the dichotomy, she may take on the duties of the professionals and be in a position of authority above the patients.

Parker et al. (1995) note that pathology versus normality, reason versus unreason, professional views versus patient views are culturally produced as binary opposites. These make certain versions of reality thinkable and practicable, while excluding others. From this perspective, the categories "staff" and "patient" just as "pathology" and "normality" may be seen as regulating and dividing practices that differentiate between people. Such dividing practices affect the categories of behavior that are considered pathological, removing them from the realm of normalcy, and thus from being understood within their social context. Rosenhan (1973) has demonstrated that whatever psychiatric patients do at a ward, their behavior can be interpreted as pathological simply because they have been labeled psychiatric patients. Similarly, whatever I seemed to do at the ward, because I was not a psychiatric patient, I was constructed by the professionals as non-patient and therefore closer to the members of staff. This is indicative of a discursive norm that produces the categories "patient" and "staff" as binary, with little leverage for negotiating spaces in between. Thus, just as the binary pairs were active in positioning the researcher constantly during fieldwork, with few possibilities of negotiating positions "in between", so might the binaries have been difficult to penetrate for both patients and professionals.

\section{Concluding reflections across fields}

The paper illustrates the importance of reading the processes of researcher-participant positioning as sources of data. This perspective invites us to see methodological problems as based on discursive norms that operate within the field. In the study, the researcher positions that were made available became an important source of knowledge about the discursive norms and social categories that operated within the mental health services.

Firstly, throughout the fieldwork, the categories "patient" and "professional", and the binary pairs "pathology" and "normality" worked as a structuring norm in all my interactions with participants. It seemed as if in order to get closer to the patients and understand how they made sense of their experiences within the mental health services, I often had to be positioned as "least staff"; while for the professionals to relate to me I had to be positioned as "least patient". Just as discourses of sanity and insanity provided categories that structured the researcherparticipant interactions, they appeared to provide boundaries that shaped how the patients and professionals could be defined. The problems associated with negotiating a position from which 
I could reach both groups therefore seemed to be indicative of the norms and dividing practices that separate patients and professionals.

Secondly, the patients' expectations that I wanted them to talk about "illness" indicate the power of biomedical discourses in structuring how the patients define themselves in relation to the mental health services. At the same time, the patients who participated in the study were far from passive in their interactions with me and in their self-positionings. They resisted the objectifying practices of the researcher as well as those of the mental health services in several ways. This capacity to resist psychiatric discourses is often downplayed in the literature on psychiatric institutions and patient identities. However, during the study it became evident that discourses of resistance became more available to the patients when they could position me as "non or least staff" or when I could join them in settings that were seen as "other" than psychiatric. This indicated that the patients modulated what could be said in accordance with the demands of the discursive context.

Thirdly, the reactions of the professionals to my presence were to position me as "least patient" and sometimes as a powerful evaluator who had the right to criticize them. These, I have argued, can be read as indicative of a discourse that polarizes pathology and normality and of a norm that sets adhering to standards as an ideal for professionalism. This indicates that, just like the patients, the professionals were not entirely free, but relied on discursive norms that formed what they could do and how they could understand themselves.

The paper thus points to the importance of understanding researcher-participant relationships as processes of positioning among people who are already positioned in different ways. The centrality of a discourse of pathology in the researcher-participant relationships indicates the power of this discourse in shaping interactions in the institution. However it also indicates that the institution is embedded in a wider cultural reality that puts in place a firm distinction between normality and deviance (Jensen, 2009). In conclusion, then, the paper shows that researcher-participant positioning is shaped by pre-existing discursive norms, but also that psychiatric patients, who are often thought of as marginalized and passive, are active and reflexive when they position themselves in relation to the mental health services.

This raises some questions regarding service user involvement and patient-centered care. Service user involvement is often defined as treatment: "taking as a starting point the patient's experiences and wishes" (Region Sjælland Psykiatri, 2010:3, my translation). Such a statement assumes an uncomplicated and static relationship between patients, their wishes and the role of the mental health services. However, as we have seen, these are not free from issues of positioning, constraints of the discursive context and dominant discourses. If patients learn that they are valued and regarded as competent insofar as they demonstrate a willingness to accept and actively adapt the understandings of the mental health services, the question of how to involve their perspectives in the treatment is not a straightforward matter. Furthermore, service-user involvement is often constructed as a concept that can be implemented smoothly if the individual professionals are more attentive to the wishes of patients. However, the analysis indicates that the actions of professionals are never entirely free, but rely on interplays of wider discourses that form what they can do. If professionals undermine their own reflexive choices in the face of standards and benchmarking - and if patients learn not to ask questions or challenge prevailing discourses and norms - the question of involving patients' perspectives is a complex matter that does not only depend on the willingness or the personal characteristics of professionals and patients. 


\section{Acknowledgements}

I thank the anonymous reviewer, whose comments improved the points advanced in the paper. I also thank Annegrethe Ahrenkiel, Erik Simonsen, Anna Llewellyn, Daniel Direktor and Annekatrine Wangel for reading and commenting on earlier drafts of the manuscript.

\section{References}

Angrosino, M. V. and Mays de Pérez, K. A. (2000). Rethinking Observation. From Method to Context. In N. K. Denzin and Y. S. Lincoln (Eds.), Handbook of Qualitative Research (2 ${ }^{\text {nd }}$ ed.). London: Sage

Barrett, R. (1996). The Psychiatric Team and the Social Definition of Schizophrenia. An Anthropological Study of Person and Illness. USA: Cambridge University Press

Borbasi, S., Jackson, D. and Wilkes, L. (2005). Fieldwork in nursing research: positionality, practicalities and predicaments. Journal of Advanced Nursing, 51 (5): 493-501

Boyle, M. (2011). Making the World Go Away, and How Psychology and Psychiatry Benefit. In M. Rapley, J. Moncrieff and J. Dillon (Eds.), De-medicalizing Misery. Psychiatry, Psychology and the Human Condition. GB: Palgrave Macmillian

Buus, N. (2005). Communication among mental health nurses: A field study of mental health nursing practices. Odense: Faculty of Health Sciences. University of Southern Denmark

Caudill, W. (1958). The Psychiatric Hospital as a Small Community. Cambridge: Harvard University Press

Davies, B. and Harré, R. (1990). Positioning: The discursive production of selves. Journal for the Theory of Social Behaviour, 20 (1): 43-63

DeRoche, K.K and Lahman, M. K. E. (2008). Methodological Considerations for Conducting Qualitative Interviews with Youth Receiving Mental Health Services. Forum: Qualitative Social Research, 9 (3): 1-18

DeWault, K. M. and DeWault, B. R. (2002). Participant Observation. A Guide for Fieldworkers. Oxford: AltaMira Press

Dillon, J. (2011). The Personal is the Political. In M. Rapley, J. Moncrieff and J. Dillon (Eds.), Demedicalizing Misery. Psychiatry, Psychology and the Human Condition. GB: Palgrave Macmillian

Emerson, R. M., Fretz, R.I. and Shaw, L.L (1995). Writing Ethnographic Fieldnotes. London: The University of Chicago Press

Estroff, S. (1981). Making it Crazy. An Ethnography of Psychiatric Clients in an American Community. USA: University of California Press

Fog, J. (2004). Med samtalen som udgangspunkt. København: Akademisk Forlag 
Foucault, M (1991a) [1984]. Truth and Power. In P. Rabinow (Ed.). The Foucault Reader. London: Penguin Books

Foucault, M. (1991b) [1977]. Discipline and Punish. The Birth of the Prison. GB: Penguin Books

Foucault, M. (2003). [1963]. The Birth of the Clinic. An archeology of medical perception. GB: Routledge

Foucault, M. (2005). [1964]. Madness and Civilization. GB: Routledge

Glesne, C. and Peshkin, A. (1999). Becoming qualitative researchers. Reading, MA: AddisonWesley

Grigg, M., Endacott, R. Herrman, H. and Harve, C. (2004). An ethnographic study of three mental health triage programs. International Journal of Mental Health Nursing, 13, 146-151

Hammersley, M. and Atkinson, P. (2007). Ethnography. Principles in practice. (3 ${ }^{\text {rd }}$ ed.). London: Routledge

Harré, R. and van Langenhove, L. (Eds.) (1999). Positioning Theory: Moral Contexts of Intentional Actions. Malden, MA: Blackwell

Harrington, B. (2003). The Social Psychology of Access in Ethnographic Research. Journal of Contemporary Ethnography, 32 (5): 592-625

Hastrup, K. (2010). Feltarbejde. In S. Brinkmann and L. Tanggaard (Eds.). Kvalitative metoder: En grundbog. København: Hans Reitzels Forlag.

Holen, M. (2011). Medinddragelse og lighed - en god idé? En analyse af patienttilblivelser i det moderne hospital. PhD Dissertation. Department of Psychology and Educational Studies. Roskilde University

Holen, M. and Ahrenkiel, A. (2011). 'After all, you should rather want to be at home'. Responsibility as a means to patient involvement in the Danish health system. Journal of Social Work Practice, 25 (3): 297-310.

Järvinen, M. and Mik-Meyer, N. (2006). Kvalitative metoder $i$ et interaktionistisk perspektiv. Interview, observationer, dokumenter. København: Hans Reizels Forlag

Jefferson, A.M. and Huniche, L. (2009). (Re)Searching for Persons in Practice: Field-Based Methods for Critical Psychological Practice Research. Qualitative Research in Psychology, 6(1-2): $12-27$

Jensen, S. Q. (2009). "Er det noget med bander?" - Om modstand, andenhed og positioner i et sociologisk feltarbejde. Dansk Sociologi, 1 (20): 46-63

Johansen, K. S. (2006). Kultur og psykiatri - en antropologi om transkulturel psykiatri på danske hospitaler. Insitut for Antropologi, Københavns Universitet 
Jorgenson, D. (1989). Participant observation: A methodology for human studies. Newbury Park, CA: Sage

Khawaja, M. and Mørck, L. L. (2009). Researcher Positioning: Muslim "Otherness" and Beyond. Qualitative Research in Psychology, 6 (1-2): 28-45

Kvale, S. and Brinkmann, S. (2009). InterViews: learning the craft of qualitative research interviewing. London: Sage

Lester, R. J. (2009). Brokering Authenticity. Borderline Personality Disorder and the Ethics of Care in an American Eating Disorder Clinic. Current Anthropology, 50 (3): 281-302

Magnussen, J., Vrangbæk, K. and Saltman, R.B. (Eds.). (2009). Nordic Health Care Systems. Recent Reforms and Current Policy Challenges. Berkshire: McGraw Hill

Mandell, N. (1988). The Least-Adult Role in Studying Children. Journal of Contemporary Ethnography, 16 (4): 433-468

McGrath, L. (2012). Heterotopias of mental health care: the role of space in experiences of distress, madness, and mental health service use. PhD dissertation. London SouthBank University

Parker, I., Georgaca, E., Harper, D., McLaughlin, T. and Stowell-Smith, M. (1995). Deconstructing Psychopathology. London: Sage

Potter, J. (1997). Discourse analysis as a way of analysing naturally occurring talk. In D. Silverman (Ed.), Qualitative Research: Theory, Method and Practice. London: Sage

Preissle, J. and Grant, L. (2004). Fieldwork traditions: Ethnography and participant observation. In K.B. deMarrais and S.D. Lapan (Eds.), Foundations for research: Methods of inquiry in education and the social sciences. Mahweh, NJ: Lawrence Erlbaum.

Rapley, M., Moncrieff, J. and Dillon, J. (Eds.), (2011). De-medicalizing misery. Psychiatry, psychology and the human condition. GB: Palgrave Macmillian

Region Sjælland Psykiatri (2010). Brugerstyret Psykiatri. Skitse og ideer til lokal implementering. Psykiatrien Region Sjælland

Rosenhan, D. L. (1973). On Being Sane in Insane Places. Science, 179: 250-258

Savvakis, M. and Tzanakis, M. (2004). The Researcher, the Field and the Issue of Entry: Two Cases of Ethnographic Research Concerning Asylums in Greece. Sociological Research Online, 9 (2). Available at: http://www.socresonline.org.uk/9/2/savvakis.html

Skeggs, B. (1997). Formations of Class and Gender. London: Sage

Snow, D. A. (1986). Fieldwork Roles and Informational Yield: A Comparison of Alternative Settings and Roles. Urban Life, 14 (4): 377-408 
Spanger, M. (2010). Destabilizing Sex Work \& Intimacy? Gender Performances of Female Thai Migrants Selling Sex in Denmark. PhD Dissertation. Department of Society and Globalisation, Roskilde University

Speed, E. (2011). Discourses of Acceptance and Resistance: Speaking Out about Psychiatry. In M. Rapley, J. Moncrieff and J. Dillon (Eds.), De-medicalizing Misery. Psychiatry, Psychology and the Human Condition. GB: Palgrave Macmillian

Søndergaard, D.M. (2006). Tegnet på kroppen. - Køn: koder og konstruktioner blandt unge voksne $i$ Akademia. København: Museum Tusculanum

Søndergaard, K.D. (2009). Innovating Mental Health Care - A configurative Case Study in Intangible, Incoherent and Multiple Efforts. The Danish School of Education. Aarhus University

van der Geest, S. and Finkler, K. (2004). Hospital ethnography: introduction. Social Science $\mathcal{E}$ Medicine, 59: 1995-2001

van Der Geest, S. and Sarkodie, S. (1998). The fake patient: a research experiment in a Ghanaian hospital. Social Science \& Medicine, 47 (9): 1373-1381

Warming, H. (2005). Erkendelse gennem oplevelse: Når indlevelse ikke er mulig. In M. Järvinen and N. Mik-Meyer (Eds.), Kvalitative metoder $i$ et interaktionistisk perspektiv. København: Hans Reitzels

Warren, C. A. B. (1983). The Politics of Trouble in in an Adolescent Psychiatric Hospital. Journal of Contemporary Ethnography, 12: 327-348

Weiss, M. (1993). Bedside manners: Paradoxes of physician behavior in grand rounds. Culture, Medicine \& Psychiatry, 17 (2): 235-254.

Wetherell, M. (2010). Themes in Discourse Research: The Case of Diana. In M. Wetherell, Taylor, S. and Yates, S. J. (Eds.), Discourse Theory and Practice. A Reader. London: Sage

Wind, G. (2008). Negotiated interactive observation: Doing fieldwork in hospital settings. Anthropology \& Medicine, 15 (2): 79-89

Author

Agnes Ringer, Msc. Psy, is a PhD candidate at the Psychiatric Research Unit and District East Psychiatry, Region Zealand, and at the Department of Psychology and Educational Studies, Roskilde University, Denmark. Email: agmr@regionsjaelland.dk or agnesri@ruc.dk 